\title{
Title: Multiple and quantitative measurements using computed tomography images reveal the factors associated with chronic subdural hematoma recurrence
}

Hiroaki Hashimoto, MD, Ph.D ${ }^{1,2 *}$; Tomoyuki Maruo MD, Ph.D ${ }^{1,3 *}$; Yukitaka Ushio MD, Ph.D ${ }^{1}$; Masayuki Hirata MD, Ph.D ${ }^{2,3}$; Haruhiko Kishima MD, Ph.D ${ }^{3}$

1. Department of Neurosurgery, Otemae Hospital, Osaka, Osaka, 540-0008, Japan

2. Department of Neurological Diagnosis and Restoration, Graduate School of Medicine, Osaka University, Suita, Osaka, 565-0871, Japan

3. Department of Neurosurgery, Graduate School of Medicine, Osaka University, Suita, Osaka, 5650871, Japan

\begin{abstract}
Objective: The aim of this retrospective single-center study was to quantitatively assess chronic subdural hematomas (CSDHs), reveal the correlations between multiple and quantitative values calculated from computed tomography images, and determine the risk factors for CSDH recurrence.
\end{abstract}

Methods: We enrolled 225 patients who underwent 304 burr-hole surgeries between April 2005 and October 2021 at Otemae Hospital. Patients' medical records and quantitative values including preoperative CSDH volume $(\mathrm{ml})$, thickness $(\mathrm{mm})$, computed tomography values (CTV), postoperative CSDH volume $(\mathrm{ml})$, and air volume $(\mathrm{ml})$ were evaluated. The locations of CSDH thickness and burr holes were also assessed quantitatively using Montreal Neurological Institute coordinates. Univariate and multivariate regression analyses and receiver operating characteristic (ROC) analyses were performed.

Results: Thirty-seven patients (12\%) showed CSDH recurrence requiring reoperation. Preoperative CSDH volume was positively correlated with age, preoperative CSDH thickness, CTV, postoperative $\mathrm{CSDH}$ volume, and air volume. Univariate Cox proportional hazards regression analysis showed that age, preoperative CSDH volume, Glasgow Coma Scale score (3-14), postoperative hemiplegia, and gait disturbance were risk factors for recurrence requiring reoperation, and a higher CTV (hazard ratio 0.95, 95\% confidence interval 0.91-0.99) was associated with a lower risk of recurrence requiring reoperation. Only preoperative CSDH volume was a significant risk factor for recurrence requiring reoperation in multivariate regression analyses. The postoperative air volume and locations of CSDH thickness and burr hole had no influence on recurrence requiring reoperation. ROC curve analysis revealed that the optimal preoperative CSDH volume cut-off value as a predictor was $155 \mathrm{ml}$, the thickness was approximately $36.3 \mathrm{~mm}$ calculated from a regression line.

Conclusions: A larger and more hypodense CSDH has a high risk of recurrence requiring reoperation. Residual air volume after surgery and locations of CSDH and burr hole had no influence on recurrence requiring reoperation. 
Submitting and Corresponding Author

Hiroaki Hashimoto

Neurosurgeon/Medical staff, Department of Neurosurgery, Otemae Hospital, Osaka, 540-0008, Japan

Corresponding Author's Email:h-hashimoto1986@,otemae.gr.jp

Corresponding Author

Tomoyuki Maruo

Neurosurgeon/Head of Neurosurgery Department, Department of Neurosurgery, Otemae Hospital, Osaka, 540-0008, Japan

Corresponding Author's Email: t-maruo@otemae.gr.jp

Key Words: chronic subdural hematoma, quantitative measurement, correlation analysis, computed tomography, recurrence requiring reoperation, burr-hole surgery

\author{
Abbreviations \\ AUC, area under the curve \\ CI, confidence interval \\ $\mathrm{CSDH}$, chronic subdural hematoma \\ CT, computed tomography \\ CTV, computed tomography values \\ DICOM, digital imaging and communication in medicine \\ GCS, Glasgow Coma Scale \\ HR, hazard ratio \\ $\mathrm{nRrR}$, non-recurrence requiring reoperation \\ $\mathrm{OR}$, odds ratio \\ ROC, receiver operating characteristic \\ $\mathrm{RrR}$, recurrence requiring reoperation \\ $\mathrm{SD}$, standard deviation
}


medRxiv preprint doi: https://doi.org/10.1101/2022.01.03.22268707; this version posted January 5, 2022. The copyright holder for this preprint (which was not certified by peer review) is the author/funder, who has granted medRxiv a license to display the preprint in perpetuity.

It is made available under a CC-BY-NC-ND 4.0 International license.

\section{Introduction}

Neurosurgeons frequently encounter chronic subdural hematomas (CSDHs), which occur in approximately $80-120$ per 100,000 persons in the aged population ${ }^{1,2}$ and is predicted to become the most frequent cranial neurosurgical condition among adults in the future. ${ }^{1,3}$ Burr-hole surgery with a closed drainage system is a simple operation that is effective for $\mathrm{CSDH}^{4-8}$ However, neurosurgeons sometimes observe CSDH recurrence. Various factors such as age,,${ }^{9,10}$ diabetes mellitus, ${ }^{9}$ and residual air after operation ${ }^{11,12}$ have been reported to be risk factors for recurrence, and recent studies evaluating CSDH quantitatively have revealed that a large volume of preoperative CSDH was a risk factor for recurrence ${ }^{13,14}$ whereas residual air was not. ${ }^{14}$ Hence, whether residual air is a risk factor for recurrence is controversial. Although previous studies involving qualitative assessments of CSDH have reported that hyperdense $\mathrm{CSDH}^{10,15,16}$ or cranial base $\mathrm{CSDH}^{17}$ were associated with a risk of recurrence, the quantitative assessment of CSDH concentration and its location remains to be performed. Furthermore, if neurosurgeons have information about the relationship between recurrence and burr-hole locations, they would have more confidence in knowing where to make a burr hole during surgery. However, the quantitative analysis of burr-hole locations associated with recurrence is limited. In this study, we hypothesized that multiple and quantitative values acquired from digital imaging and communication in medicine (DICOM) computed tomography (CT) images, such as volume, density, and CSDH as well as burr-hole locations, could reveal correlations between them and a previously unknown risk factor for recurrence requiring reoperation.

\section{Methods}

\section{Patients and Study Setting}


medRxiv preprint doi: https://doi.org/10.1101/2022.01.03.22268707; this version posted January 5, 2022. The copyright holder for this preprint (which was not certified by peer review) is the author/funder, who has granted medRxiv a license to display the preprint in perpetuity.

It is made available under a CC-BY-NC-ND 4.0 International license.

In this retrospective study, we enrolled patients who underwent surgical evacuation of CSDHs at Otemae Hospital between April 2005 and October 2021. Data on a total of 304 operative cases performed in 225 patients were collected, and all of their DICOM CT images were available. This study was approved by the Ethics Committee of the Otemae Hospital (Osaka, Japan; approval no.

CT190122034) and was conducted in accordance with the Declaration of Helsinki for experiments involving humans. Due to the retrospective and noninvasive nature of the study, informed consent was obtained using the opt-out method from our center's website.

\section{Surgical Procedure}

Surgical evacuation was performed for $\mathrm{CSDH}$, which compressed the brain and induced neurological deficits or medically intractable headaches. Under local anesthesia, a single burr hole was performed and the dura mater was cut. Subsequently, the outer membrane of the CSDH was exposed, and a silicone tube with a closed drainage system was inserted into the hematoma cavity. Irrigation of the hematoma with normal saline and the direction (anterior or posterior) of insertion of the drainage tube were left to the surgeon's discretion. A postoperative CT scan was routinely performed on the morning after the operation, and the tube was removed within $48 \mathrm{~h}$ following surgery. Until the removal of the tube, we instructed the patients to remain in the supine position in bed. We discontinued anticoagulant or antiplatelet medications temporarily before surgery in all cases, and they were resumed approximately one week after the surgery.

\section{Data Collection}

We performed CT scanning preoperatively and on the first postoperative day in all cases. CT images obtained a few months after the operation were available for 288 cases. We retrospectively 
medRxiv preprint doi: https://doi.org/10.1101/2022.01.03.22268707; this version posted January 5, 2022. The copyright holder for this preprint (which was not certified by peer review) is the author/funder, who has granted medRxiv a license to display the preprint in perpetuity. It is made available under a CC-BY-NC-ND 4.0 International license .

evaluated medical variables related to patients, including sex, age, antiplatelet medication, anticoagulant medication, and pre- and postoperative symptoms such as headache, dementia, aphasia, hemiplegia, gait disturbance, and consciousness level represented by the Glasgow Coma Scale (GCS). In 42 cases, postoperative information was not available, and in 43 cases, preoperative information was not available (Fig. 1). We defined symptoms that were observed until one week after the operation as postoperative symptoms. Data on hematoma features including hematoma laterality (left or right), bilaterality, presence of midline shift, and subtypes were collected. The subtypes consist of four types: homogeneous, laminar, separated, and trabecular, as described by Nakaguchi et al. ${ }^{17}$ Data related to treatment options, including drainage tube direction (anterior or posterior) and combination with irrigation, were collected. Since the drainage tube was not inserted in two cases, information about the drainage tube direction was collected from 302 cases. Since there was no information about irrigation in 44 cases, irrigation data were collected from 260 cases (Fig. 1). All patients were followed up as much as possible, and the duration from the first surgery to reoperation was recorded. We defined cases that showed a subsequent increase in hematoma volume in the ipsilateral subdural space with significant neurological deficits and required a second operation as cases of recurrence requiring reoperation $(\mathrm{RrR})$. Number of years since the surgeon had started neurosurgical residency was also recorded.

\section{Quantitatively Assessment for CSDH}

DICOM CT images were imported to MATLAB R2020b (MathWorks, Natick, MA, USA), and CSDH and postoperative air were segmented manually using the image segmenter app in MATLAB (https://www.mathworks.com/help/images/ref/imagesegmenter-app.html; Fig. 2A and 2B). These procedures enabled us to calculate the volume and average CT values (CTVs) of the segmented regions. We calculated the volume of CSDH preoperatively, postoperatively, and a few months later, and the 
medRxiv preprint doi: https://doi.org/10.1101/2022.01.03.22268707; this version posted January 5, 2022. The copyright holder for this preprint (which was not certified by peer review) is the author/funder, who has granted medRxiv a license to display the preprint in perpetuity. It is made available under a CC-BY-NC-ND 4.0 International license .

volume of postoperative air. The averaged CTVs were calculated from preoperative CSDH segmentations, and the standard deviation (SD) was also calculated. We defined the thickness (mm) of preoperative CSDH as the maximum horizontal width of preoperative CSDH segmentations (Fig. 2C). The drainage volume was the difference obtained from the preoperative CSDH volume minus the postoperative CSDH volume. The drainage ratio was calculated by dividing the drainage volume by the preoperative CSDH volume. The homogeneous subtypes were divided into three types according to the average CTV: hypodensity $<30,30 \leq$ isodensity $<40$, and $40 \leq$ hyperdensity.

DICOM CT images were converted into the standard brain using the Montreal Neurological Institute (MNI) coordinates using Brainstorm software (http://neuroimage.usc.edu/brainstorm/). We collected data of the MNI coordinates for the most lateral position of the CSDH thickness (indicated by a black dot in Fig. 2C) and burr hole (indicated by a white circle in Fig. 2D). We treated the thickness positions as a representation of the CSDH locations. We changed the $\mathrm{X}$ coordinates to absolute values for the evaluation. The distance between the thickness of the CSDH and the burr hole was calculated using the following equation:

$$
\text { Distance }=\sqrt[2]{\left(x_{\text {thickness }}-x_{\text {burr hole }}\right)^{2}+\left(y_{\text {thickness }}-y_{\text {burr hole }}\right)^{2}+\left(z_{\text {thickness }}-z_{\text {burr hole }}\right)^{2}}
$$

\section{Statistical Analyses}

Categorical data and continuous variables were presented as frequencies (percentages) or mean \pm SD, respectively. Clinical differences between non-RrR (nRrR) and RrR were assessed using the chisquared test for categorical variables. Since the distribution of continuous variables was a nonparametric distribution, we used the two-tailed Wilcoxon rank-sum test for continuous variables. The Kruskal-Wallis test was used to compare the four subtype groups. We calculated the Spearman correlation coefficients between the continuous variables. 
medRxiv preprint doi: https://doi.org/10.1101/2022.01.03.22268707; this version posted January 5, 2022. The copyright holder for this preprint (which was not certified by peer review) is the author/funder, who has granted medRxiv a license to display the preprint in perpetuity.

It is made available under a CC-BY-NC-ND 4.0 International license.

The receiver operating characteristic (ROC) curve was used to evaluate predictors of $\mathrm{RrR}$. The cut-off value was defined as the maximal Youden index (sensitivity + specificity - 1). Kaplan-Meier survival curves were plotted (https://github.com/dnafinder/kmplot, Curve Cardillo G, 2008), and the log-rank test was conducted to compare the time to recurrence (https://github.com/dnafinder/logrank, Cardillo G. 2008).

Univariate Cox proportional hazards regression analyses were used to calculate hazard ratios (HRs) with 95\% confidence intervals (CIs) for RrR. A univariate logistic regression model was used to calculate the odds ratio (OR) with $95 \%$ confidence intervals (CIs). The variables analyzed in the regression analyses were potential predictors, and almost all of them showed a $p$-value $<0.05$, as determined by the chi-squared test or Wilcoxon rank-sum test. We excluded variables that indicated a strong correlation in the regression analyses. Multivariable Cox proportional hazards regression and multivariable logistic regression were performed to ensure that the variables were independently predictive of RrR. Statistical analyses were performed using the Statistical and Machine Learning Toolbox of MATLAB R2020b.

\section{Data Availability}

All data in this study are available from the corresponding authors upon reasonable request and after additional ethics approval.

\section{Results}

\section{Baseline Characteristics}


medRxiv preprint doi: https://doi.org/10.1101/2022.01.03.22268707; this version posted January 5, 2022. The copyright holder for this preprint (which was not certified by peer review) is the author/funder, who has granted medRxiv a license to display the preprint in perpetuity. It is made available under a CC-BY-NC-ND 4.0 International license .

The baseline characteristics of the patients with CSDH are summarized in Table 1. Of the 304 cases (mean age 77.4 years; range 49-95 years; 80 females, 26\%), 37 cases (12\%) experienced at least one RrR, and the median interval between initial surgery and RrR was 29 days. The mean age of cases of RrR was non-significantly higher than that of $\mathrm{nRrR}$, and patients over 75 years of age showed a significantly higher recurrence rate ( $p=0.035$, chi-squared test). We used the age of 75 years because it was the cut-off value according to the ROC analysis (see the follow-up outcomes section). Laterality, bilateral CSDH, midline shift, career years of surgeons, drainage tube direction, and combination with irrigation had no influence on $\mathrm{RrR}$. Preoperative and postoperative information were available for 261 and 262 cases, respectively, and a prescription of anticoagulant and/or antiplatelet medication did not influence RrR. Pre-operative GCS score 3-14 and post-operative hemiplegia as well as gait disturbance were significantly associated with $\operatorname{RrR}(p=0.047,0.00028$, and 0.0023, respectively; chi-squared tests). Further descriptive data are presented in Table 1.

\section{Quantitative Measurement}

Pre-operatively, post-operatively, and a few months later, the CSDH volume of RrR was significantly larger than that of $\operatorname{nRR}\left(p=0.0029,0.00024\right.$, and $1.0 \times 10^{-12}$, respectively; Wilcoxon rank-sum test). Contrarily, the CTV of preoperative CSDH was significantly lower in $\mathrm{RrR}$ than in $\mathrm{nRrR}$ cases ( $p=0.0075$; Wilcoxon rank-sum test). Preoperative SD values of CTV and CSDH thickness and postoperative air volume were larger, and the drainage ratio was lower in the RrR group than in the nRrR group, but these differences were not statistically significant. The postoperative air volumes of the anterior drainage tube and posterior drainage tube were $10.3 \mathrm{ml}$ and $13.0 \mathrm{ml}$, respectively. Although the anterior drainage tube showed lesser air volume, it was not statistically significant ( $p=0.86$; Wilcoxon rank-sum test; Table 1). 
medRxiv preprint doi: https://doi.org/10.1101/2022.01.03.22268707; this version posted January 5, 2022. The copyright holder for this preprint (which was not certified by peer review) is the author/funder, who has granted medRxiv a license to display the preprint in perpetuity. It is made available under a CC-BY-NC-ND 4.0 International license .

In the four CSDH subtypes, there was no statistical difference in RrR, but laminar and separate types showed higher recurrence rates (17\% and 16\%, respectively) than the other two types. Although there were no significant differences in CTV between the four subtypes, significant differences were observed in the SD of CTV between subtypes $\left(4.9 \times 10^{-29}\right.$, Kruskal-Wallis test). In the homogeneous subtype, the hypodense hematoma was associated with a higher recurrence rate $(20 \%)$ than the isodense $(10 \%)$ and hyperdense hematomas $(9 \%)$, but the difference was not significant (Table 1$)$.

\section{MNI Coordinates of CSDH and Burr Hole}

Positive and negative $\mathrm{X}$ coordinates corresponded to the right and left sides (Fig. 3A), and we used the absolute values of $\mathrm{X}$ coordinates for assessment. In the $\mathrm{X}, \mathrm{Y}$, and $\mathrm{Z}$ coordinates of the thickness and burr-hole positions, there were no statistical differences between $\operatorname{RrR}$ and $n R r R$ cases. The $\mathrm{X}, \mathrm{Y}$, and $\mathrm{Z}$ coordinate differences between thickness and burr-hole and distance from thickness to burr-hole position showed no significant difference between $\mathrm{RrR}$ and $\mathrm{nRrR}$ cases (Table 1). All thickness and burr-hole positions were plotted over the standard brain (Fig. 3). The distribution patterns of thickness positions varied widely from anterior to posterior and from dorsal to ventral in both $\mathrm{nRrR}$ and $\mathrm{RrR}$ cases. In contrast, the distribution of burr-hole positions in both $\mathrm{nRrR}$ and $\mathrm{RrR}$ cases focused on the region where the anterior-posterior direction ranged from the frontal to temporal lobe and the height was mainly at the superior temporal line. It was possible to appreciate visually that there was no obvious difference between nRrR and RrR cases in both thickness and burr-hole positions.

\section{Correlation Analysis}

Positive and negative correlation coefficients $(p<0.05)$ are indicated as a solid line and a broken line in Figure 4A. Preoperative CSDH volume was positively correlated with postoperative CSDH 
medRxiv preprint doi: https://doi.org/10.1101/2022.01.03.22268707; this version posted January 5, 2022. The copyright holder for this preprint (which was not certified by peer review) is the author/funder, who has granted medRxiv a license to display the preprint in perpetuity. It is made available under a CC-BY-NC-ND 4.0 International license .

volume, a few months later CSDH volume, CSDH thickness, age, air volume, and CTV. There was a strong positive correlation between preoperative CSDH volume and thickness $\left(\mathrm{r}=0.60, p=9.1 \times 10^{-31}\right)$ with the corresponding regression line as follows: preoperative CSDH volume $(\mathrm{ml})=4.4 \times$ thickness (mm) - 4.8 (Fig. 4B). The drainage ratio and air volume had a negative correlation with the postoperative CSDH volume. There was a negative correlation between CTV and SD of CTV, which indicated that the higher the hematoma density, the more homogeneous the hematoma density. Age and postoperative CSDH volume had a positive correlation with the SD of CTV and a negative correlation with CTV. Thus, the older the patient was, the weaker the concentration and more heterogeneous the $\mathrm{CSDH}$; furthermore, the thicker the concentration and more homogeneous the CSDH, the smaller the postoperative CSDH volume. The distance from the thickness to the burr-hole position was not correlated with other variables.

\section{Follow-up Outcomes}

For recurrence prediction, an ROC curve was used, and the area under the curve (AUC) of preoperative CSDH volume and CTV were larger than those of postoperative air and age. According to the Youden index, the ROC analysis showed that the optimal cut-off values were $155 \mathrm{ml}$ for preoperative CSDH volume, 33 for CTV, $1.94 \mathrm{ml}$ for postoperative air, and 75 years for age (Fig. 5, upper row). We did not assess CSDH volumes postoperatively and a few months later because they had a strong positive correlation with preoperative CSDH volume.

The Kaplan-Meier curve using these cut-off values showed that most RrR cases occurred within approximately 80 days. Log-rank tests revealed that larger preoperative CSDH volume, lesser CTV, more air volume, and older age were associated with a significant risk of $\operatorname{RrR}(p=0.00051, p=0.011, p$ $=0.024$, and $p=0.024$, respectively; Fig. 5, lower row). 
medRxiv preprint doi: https://doi.org/10.1101/2022.01.03.22268707; this version posted January 5, 2022. The copyright holder for this preprint (which was not certified by peer review) is the author/funder, who has granted medRxiv a license to display the preprint in perpetuity.

It is made available under a CC-BY-NC-ND 4.0 International license .

\section{Risk Factors for Recurrence of CSDH}

Age, preoperative CSDH volume, GCS score 3-14, post-operative hemiplegia, and gait disturbance were positively associated with RrR, as revealed by univariate Cox proportional hazards regression analyses and univariate logistic regression analyses. Preoperative CTV was inversely associated with RrR, as revealed by univariate Cox proportional hazards regression analyses. The postoperative air volume was not associated with RrR (Table 2).

Multivariate Cox proportional hazards regression analyses showed that pre-operative CSDH volume (HR 1.01, 95\% CI 1.00-1.02, $p=0.024)$ and post-operative gait disturbance (HR 3.90, 95\% CI $1.62-9.38, p=0.024)$ were independent risk factors for RrR. In multivariate logistic regression analyses, only preoperative CSDH volume (HR 1.01, 95\% CI 1.00-1.02, $p=0.010$ ) was significantly associated with RrR (Table 2).

\section{Discussion}

Multiple and quantitative values acquired from DICOM CT images of CSDH patients who underwent single burr-hole surgery with a closed drainage system were assessed. Various positive or negative correlations were observed among the quantitative variables. CTV was significantly lower in RrR cases than in nRrR cases, and a hypodense subgroup $(\mathrm{CTV}<30)$ of homogeneous CSDH cases were associated with a higher RrR rate than iso- and hyperdense subgroups. Regression analyses showed that higher CTVs in CSDHs were associated with a lower risk of RrR. These results are contrary to those of previous studies. As for MNI coordinate analyses, we showed that where the CSDH was located and where the cranium was perforated had no influence on $\mathrm{RrR}$. 
medRxiv preprint doi: https://doi.org/10.1101/2022.01.03.22268707; this version posted January 5, 2022. The copyright holder for this preprint (which was not certified by peer review) is the author/funder, who has granted medRxiv a license to display the preprint in perpetuity. It is made available under a CC-BY-NC-ND 4.0 International license .

In this study, the percentage of at least one RrR was $12 \%$ and most CSDH recurred within 80 days, as revealed by the Kaplan-Meier survival curves, which was concordant with previous studies. ${ }^{9,10,16,18}$ Several factors have been reported to influence the risk of recurrence, like age, sex, diabetes mellitus, smoking, bilateral CSDH, midline shift, GCS score at admission, and high-density lipoprotein levels. ${ }^{9,10,15,18-20}$ Preoperative CSDH volume was also reported to be a factor for recurrence, ${ }^{14}$ 10,13 and we showed that a large volume of preoperative CSDH was associated with recurrence using multivariate analyses. Additionally, we demonstrated that if patients showed symptoms such as hemiplegia or gait disturbance even after burr-hole surgery, these symptoms were highly associated with RrR. If these symptoms continued after the operation and evacuation of CSDH were insufficient, it is reasonable that neurosurgeons try to perform re-operation for relief of symptoms.

Although postoperative air volume was previously thought to be a risk factor for recurrence, ${ }^{11,12}$ recent studies have demonstrated no relationship between air volume and recurrence. ${ }^{14}$ Our results obtained from both Cox proportional hazards regression and logistic regression analyses also showed that postoperative air volume was not a risk factor for recurrence. Additionally, because postoperative air volume was positively correlated with preoperative $\mathrm{CSDH}$ volume, it is reasonable to postulate that the higher the preoperative CSDH volume, the higher the recurrence rates, and the larger the postoperative air volume. Persistence of subdural air after surgery has been significantly correlated with poor brain re-expansion, ${ }^{21}$ and patients with residual subdural air seven days after surgery have been shown to have a higher recurrence rate than those without air. ${ }^{22}$ Moreover, poor brain re-expansion seven days after surgery has been shown to be a significant risk factor for recurrence, ${ }^{18}$ and cerebral atrophy is also associated with the development of $\mathrm{CSDH}^{23}$ Since approximately half of CSDH cases 
medRxiv preprint doi: https://doi.org/10.1101/2022.01.03.22268707; this version posted January 5, 2022. The copyright holder for this preprint (which was not certified by peer review) is the author/funder, who has granted medRxiv a license to display the preprint in perpetuity. It is made available under a CC-BY-NC-ND 4.0 International license .

lack a history of head injury ${ }^{21,24}$ and sufficient subdural space is thought to be a prerequisite for developing $\mathrm{CSDH}$, Lee claimed that $\mathrm{CSDH}$ should be categorized as a degenerative lesion instead of a traumatic lesion. ${ }^{25}$ Therefore, we infer that a true risk factor for recurrence of CSDH may be poor reexpansion of the brain, and postoperative air volume may be the result, and not a cause, of poor brain reexpansion.

While burr-hole surgery with a closed drainage system is effective for $\mathrm{CSDH}^{4-8}$ studies have investigated where to perforate the cranium, and the quantitative assessment of the position of burr holes remains unclear. Empirically, burr holes were created overlying the hematoma and were mainly on the superior temporal line, ranging in location from the frontal to the temporal lobe. ${ }^{7}$ In this study, using MNI coordinates, we found that there was no significant spatial difference in the burr-hole locations between RrR and nRrR cases. We confirmed that the location of burr holes had no influence on recurrence. Moreover, we demonstrated that burr holes were mainly located on the superior temporal line and ranged from the frontal to temporal lobe (Fig. 3), which fitted our empirical knowledge. As for the position of $\mathrm{CSDH}$, the recurrence rate of cranial base CSDH was reported to be high. ${ }^{17}$ However, our results demonstrated that the location of $\mathrm{CSDH}$ thickness ranged widely from the frontal to occipital lobe and from the skull base to the superior temporal line, and there were no significant spatial differences in CSDH locations between the RrR and nRrR cases.

As for the surgical technique, some previous studies that treated postoperative air as a risk factor for recurrence reported that for reduction of air, a patient's head position should be arranged to make burr-holes at the highest level in the operative field ${ }^{26}$ and a drainage tube should be inserted into the frontal convexity. ${ }^{22}$ Although our results showed a lower air volume in the anterior direction of the tube 
medRxiv preprint doi: https://doi.org/10.1101/2022.01.03.22268707; this version posted January 5, 2022. The copyright holder for this preprint (which was not certified by peer review) is the author/funder, who has granted medRxiv a license to display the preprint in perpetuity. It is made available under a CC-BY-NC-ND 4.0 International license .

than in the posterior direction, this difference was not statistically significant. Furthermore, the direction of the drainage tube had no influence on recurrence, and the postoperative air volume in the RrR group was not significantly larger than that in the $\mathrm{nRrR}$ group with either anterior or posterior directions of the tube. These results also support the notion that postoperative air is not a risk factor for recurrence. Although irrigation has been reported to be associated with a lower recurrence rate, ${ }^{5}$ our results showed no statistically significant effectiveness of irrigation. Since the career years of operating surgeons was not significantly different between $\mathrm{nRrR}$ and RrR cases, we infer that burr-hole surgery for CSDH is a safe procedure for neurosurgical residents to perform.

We demonstrated that laminar and separate subtypes had higher recurrence rates than the other two CSDH subtypes, which is concordant with previous studies. ${ }^{14,16,17} \mathrm{We}$ demonstrated that CTV was not significantly different, but the SD of CTV was significantly different among subtypes. The homogeneous type showed the smallest SD values, which represented a visually uniform hematoma, and the separate type showed the highest SD values, which represented a wide dispersion of CTV because the separate type had a two-layer structure consisting of hypodense and iso- or hyperdense hematoma. We evaluated differences in CSDH subtypes objectively, and these results support our calculation of CTV and its SD for assessment of the nature of CSDH.

Previous studies have reported that hyperdense hematoma is associated with recurrence. ${ }^{10,14-16}$ However, we demonstrated that CTV in RrR cases was significantly lower than that in nRrR cases; furthermore, lower recurrence rates were observed in the higher CTV group in the Kaplan-Meier survival analysis, and HR was significantly lower $(<1)$ in the univariate Cox proportional hazards regression analysis. Moreover, we classified the homogeneous CSDH subtype into three groups, hypo-, 
medRxiv preprint doi: https://doi.org/10.1101/2022.01.03.22268707; this version posted January 5, 2022. The copyright holder for this preprint (which was not certified by peer review) is the author/funder, who has granted medRxiv a license to display the preprint in perpetuity. It is made available under a CC-BY-NC-ND 4.0 International license .

iso-, and hyperdensity according to CTV, and the hypodense group showed the highest recurrence rate. Although our results are in contrast to previous findings, we believe that our results are reliable and novel because we used objective measurements. A subdural hygroma is thought to be a collection of cerebrospinal fluid without blood due to traumatic arachnoid tearing, ${ }^{17,25}$ and CT images of hygroma show hypodensity. ${ }^{27,28}$ Nearly $50 \%$ of patients with a subdural hygroma develop CSDH, ${ }^{25}$ and the effect of surgery for hygroma is poor. ${ }^{29,30}$ Therefore, we inferred that our results might be related to the poor surgical outcomes associated with hygroma. Of course, all cases in this study were diagnosed as CSDH and not hygroma by at least one neurosurgery specialist certified by the Japan Neurosurgical Society.

We demonstrated detailed correlation relationships among the quantitative parameters. Preoperative CSDH volume, which is associated with recurrence, was positively correlated with several parameters. Previous studies have reported that postoperative CSDH volume ${ }^{14,31}$ and CSDH thickness ${ }^{6,15,32}$ were associated with recurrence. However, the above two parameters were positively correlated with preoperative $\mathrm{CSDH}$ volume, and we infer that the true factor influencing recurrence is preoperative CSDH volume. In a clinical situation, it is difficult to calculate the preoperative CSDH volume quickly and easily from CT images. Therefore, we presented a regression line between CSDH thickness (mm) and preoperative $\mathrm{CSDH}$ volume (ml). A preoperative $\mathrm{CSDH}$ volume of $155 \mathrm{ml}$, which was calculated from the maximal Youden index (Fig. 5), corresponds to $36.3 \mathrm{~mm}$ (Fig. 4). CSDH that are over $36.3 \mathrm{~mm}$ in thickness may require particularly close monitoring. As postoperative CSDH volume was negatively related to CTV and positively SD, hypodensity and non-uniform CSDH tended to be larger after surgery. As age was positively related to preoperative CSDH volume, CTV negatively, and its SD positively, we can infer that an older patient tends to have a larger, more hypodense, and more ununiform hematoma. The drainage ratio has a positive correlation with postoperative air volume, 
medRxiv preprint doi: https://doi.org/10.1101/2022.01.03.22268707; this version posted January 5, 2022. The copyright holder for this preprint (which was not certified by peer review) is the author/funder, who has granted medRxiv a license to display the preprint in perpetuity. It is made available under a CC-BY-NC-ND 4.0 International license .

which was also highlighted in a previous study. ${ }^{26}$ Because our regression analyses revealed that larger preoperative CSDH volume and lesser CTV were correlated with recurrence, if there was any correlation between them, we would have expected a negative correlation. However, a positive correlation was observed. Therefore, we inferred that the preoperative CSDH volume and CTV were independent factors for recurrence, and we could only state that hyperdense CSDH tended to be larger.

This study has some limitations. We focused on only single burr-hole surgery, not other types of surgery, such as two burr-hole surgeries or twist drill surgery. ${ }^{7}$ It is unclear whether the same results would be obtained from these other types of surgery. Second, although there may be a positive relationship between preoperative $\mathrm{CSDH}$ volume and the degree of brain atrophy, we could not determine the relationship because we did not measure brain volume in this study. We infer that there may be some relationship between recurrence, preoperative CSDH volume, degree of brain atrophy, and poor brain re-expansion. Finally, as it was possible that surgeons made efforts to reduce the postoperative air volume, this could have introduced some bias into the results.

\section{Conclusions}

Patient profiles such as preoperative CSDH volume, age, and CTV of the hematoma were related to $\mathrm{CSDH}$ recurrence. However, technical issues related to burr-hole surgery, such as where to perforate the cranium, the direction of the drainage tube, and irrigation, were not related to recurrence. Postoperative air volume was positively correlated with preoperative CSDH volume and was not a risk factor for recurrence. In cases of large volume and low concentration CSDH, attention should be paid to recurrence. 
medRxiv preprint doi: https://doi.org/10.1101/2022.01.03.22268707; this version posted January 5, 2022. The copyright holder for this preprint (which was not certified by peer review) is the author/funder, who has granted medRxiv a license to display the preprint in perpetuity.

\author{
It is made available under a CC-BY-NC-ND 4.0 International license.
}


medRxiv preprint doi: https://doi.org/10.1101/2022.01.03.22268707; this version posted January 5, 2022. The copyright holder for this preprint (which was not certified by peer review) is the author/funder, who has granted medRxiv a license to display the preprint in perpetuity.

It is made available under a CC-BY-NC-ND 4.0 International license.

Disclosures:

This work was supported by the Japan Society for the Promotion of Science (JSPS) KAKENHI [JP21K16629 (Hiroaki Hashimoto)]. No authors have any conflicts of interest to disclose.

Acknowledgments:

We would like to thank Dr. Yuki Kimoto, Dr. Masami Nakamura, and Dr. Takahiro Fujinaga for treating the patients.

Authors' Contributions:

HH conceived this study, collected the data, created the MATLAB program, analyzed the data, created all figures, and was primarily responsible for writing the manuscript. HH and TM discussed the interpretation of the results. MH provided the technical support. TM, YU, and HK supervised the study. All authors reviewed the manuscript. 
medRxiv preprint doi: https://doi.org/10.1101/2022.01.03.22268707; this version posted January 5, 2022. The copyright holder for this preprint (which was not certified by peer review) is the author/funder, who has granted medRxiv a license to display the preprint in perpetuity. It is made available under a CC-BY-NC-ND 4.0 International license.

\section{References}

1. Balser D, Farooq S, Mehmood T, Reyes M, Samadani U. Actual and projected incidence rates for chronic subdural hematomas in United States Veterans Administration and civilian populations. $J$ Neurosurg. 2015;123(5):1209-1215.

2. Rauhala M, Luoto TM, Huhtala $\mathrm{H}$, et al. The incidence of chronic subdural hematomas from 1990 to 2015 in a defined Finnish population. J Neurosurg. 2019;132(4):1147-1157.

3. Neifert SN, Chaman EK, Hardigan T, et al. Increases in Subdural Hematoma with an Aging Population - the Future of American Cerebrovascular Disease. World Neurosurg. 2020;141:e166-e174.

4. Okada Y, Akai T, Okamoto K, Iida T, Takata H, Iizuka H. A comparative study of the treatment of chronic subdural hematoma - burr hole drainage versus burr hole irrigation. Surg Neurol. 2002;57(6):405-409.

5. Liu W, Bakker NA, Groen RJ. Chronic subdural hematoma: a systematic review and metaanalysis of surgical procedures: a systematic review. J Neurosurg. 2014;121(3):665-673.

6. Glancz LJ, Poon MTC, Hutchinson PJ, Kolias AG, Brennan PM. Drains result in greater reduction of subdural width and midline shift in burr hole evacuation of chronic subdural haematoma. Acta Neurochir (Wien). 2020;162(6):1455-1466.

7. Ertilav K, Kocaman Ü, Önder A. Surgical Treatment of Chronic Subdural Hematoma. Subdural Hematoma. Springer; 2021:373-384.

8. Liu L-X, Cao X-D, Ren Y-M, Zhou L-X, Yang C-H. Risk factors for recurrence of chronic subdural hematoma: a single center experience. World Neurosurg. 2019;132:e506-e513.

9. Liu W-C, Lin Q-Q, Jin J, et al. An association of low high-density lipoprotein levels with recurrence of chronic subdural hematoma. Acta Neurochir (Wien). 2021;163(4):1061-1068.

10. Yan C, Yang M-f, Huang Y-w. A reliable nomogram model to predict the recurrence of chronic subdural hematoma after burr hole surgery. World Neurosurg. 2018;118:e356-e366.

11. Yu GJ, Han CZ, Zhang M, Zhuang HT, Jiang YG. Prolonged drainage reduces the recurrence of chronic subdural hematoma. British Journal of Neurosurgery. 2009;23(6):606-611.

12. Oishi M, Toyama M, Tamatani S, Kitazawa T, Saito M. Clinical factors of recurrent chronic subdural hematoma. Neurol Med-Chir. 2001;41(8):382-386.

13. Xu F-F, Chen J-H, Leung GKK, et al. Quantitative computer tomography analysis of postoperative subdural fluid volume predicts recurrence of chronic subdural haematoma. Brain Inj.

2014;28(8):1121-1126.

14. Stanišić M, Hald J, Rasmussen IA, et al. Volume and densities of chronic subdural haematoma obtained from CT imaging as predictors of postoperative recurrence: a prospective study of 107 operated patients. Acta Neurochir (Wien). 2013;155(2):323-333.

15. Miah IP, Tank Y, Rosendaal FR, et al. Radiological prognostic factors of chronic subdural hematoma recurrence: a systematic review and meta-analysis. Neuroradiology. 2021;63(1):27-40.

16. Stanišić M, Pripp AH. A reliable grading system for prediction of chronic subdural hematoma recurrence requiring reoperation after initial burr-hole surgery. Neurosurgery. 2017;81(5):752-760.

17. Nakaguchi H, Tanishima T, Yoshimasu N. Factors in the natural history of chronic subdural hematomas that influence their postoperative recurrence. J Neurosurg. 2001;95(2):256-262.

18. Jang KM, Choi HH, Mun HY, Nam TK, Park YS, Kwon JT. Critical depressed brain volume influences the recurrence of chronic subdural hematoma after surgical evacuation. Sci Rep.

2020;10(1):1-8. 
medRxiv preprint doi: https://doi.org/10.1101/2022.01.03.22268707; this version posted January 5, 2022. The copyright holder for this preprint (which was not certified by peer review) is the author/funder, who has granted medRxiv a license to display the preprint in perpetuity. It is made available under a CC-BY-NC-ND 4.0 International license.

19. Greuter L, Lutz K, Fandino J, Mariani L, Guzman R, Soleman J. Drain type after burr-hole drainage of chronic subdural hematoma in geriatric patients: a subanalysis of the cSDH-Drain randomized controlled trial. Neurosurg Focus. 2020;49(4):E6.

20. Kung W-M, Hung K-S, Chiu W-T, et al. Quantitative assessment of impaired postevacuation brain re-expansion in bilateral chronic subdural haematoma: possible mechanism of the higher recurrence rate. Injury. 2012;43(5):598-602.

21. Mori K, Maeda M. Surgical treatment of chronic subdural hematoma in 500 consecutive cases: clinical characteristics, surgical outcome, complications, and recurrence rate. Neurol Med-Chir. 2001;41(8):371-381.

22. Nakaguchi H, Tanishima T, Yoshimasu N. Relationship between drainage catheter location and postoperative recurrence of chronic subdural hematoma after burr-hole irrigation and closed-system drainage. J Neurosurg. 2000;93(5):791-795.

23. Yang AI, Balser DS, Mikheev A, et al. Cerebral atrophy is associated with development of chronic subdural haematoma. Brain Inj. 2012;26(13-14):1731-1736.

24. Park H-R, Lee K-S, Shim J-J, Yoon S-M, Bae H-G, Doh J-W. Multiple densities of the chronic subdural hematoma in CT scans. Journal of Korean Neurosurgical Society. 2013;54(1):38.

25. Lee K-S. History of chronic subdural hematoma. Korean journal of neurotrauma.

2015;11(2):27-34.

26. Nagata K, Asano T, Basugi N, Tango T, Takakura K. Studies on the operative factors affecting the reduction of chronic subdural hematoma, with special reference to the residual air in the hematoma cavity. No Shinkei Geka. 1989;17(1):15-20.

27. Akhaddar A. Cranial Chronic Subdural Hematoma Following Traumatic Subdural Hygroma. Subdural Hematoma. Springer; 2021:199-208.

28. Akhaddar A. Neuroimaging Differential Diagnosis (Imaging Mimicking Conditions) of Cranial Chronic Subdural Hematoma. Subdural Hematoma. Springer; 2021:311-326.

29. Lee K, Bae W, Park Y, Yun I. The pathogenesis and fate of traumatic subdural hygroma. British journal of neurosurgery. 1994;8(5):551-558.

30. Lee KS, Bae WK, Bae HG, Yun IG. The fate of traumatic subdural hygroma in serial computed tomographic scans. J Korean Med Sci. 2000;15(5):560-568.

31. Kanazawa T, Takahashi S, Minami Y, Jinzaki M, Toda M, Yoshida K. Prediction of postoperative recurrence of chronic subdural hematoma using quantitative volumetric analysis in conjunction with computed tomography texture analysis. J Clin Neurosci. 2020;72:270-276.

32. Yamamoto H, Hirashima Y, Hamada H, Hayashi N, Origasa H, Endo S. Independent predictors of recurrence of chronic subdural hematoma: results of multivariate analysis performed using a logistic regression model. J Neurosurg. 2003;98(6):1217-1221. 
medRxiv preprint doi: https://doi.org/10.1101/2022.01.03.22268707; this version posted January 5, 2022. The copyright holder for this preprint (which was not certified by peer review) is the author/funder, who has granted medRxiv a license to display the preprint in perpetuity.

Figure Legend:

Fig. 1. Flow chart showing cases investigated in this study.

Fig. 2. Processing of DICOM CT images of patients with CSDH. A. CT images of a same CSDH case pre-operatively, post-operatively, and a few months later. B. Segmentation of CSDH and air are indicated by black and gray colors, respectively. The shown segmentations were acquired from the images in panel A. C. The maximum width of CSDH is indicated by a red line, which is $31 \mathrm{~mm}$. We treated this width as the thickness of CSDH. The most lateral position is indicated as a black-filled circle, whose MNI coordinates are shown. This image is the same as the middle pre-operative image in panel A. D. The position of a single burr hole is indicated as a white circle, whose MNI coordinates were shown.

Fig. 3. Distribution of CSDH thickness and burr-hole positions. According to MNI coordinates, the thickness position of CSDH (upper row) and burr-hole position (lower row) are plotted over the MNI standard brain. Cases of nRrR and RrR are indicated as yellow and red circles, respectively. The circles are scaled linearly to the pre-operative CSDH volume. Axial slices (X-Y plane), coronal slices (X-Z plane), and sagittal slices (Y-Z plane) are indicated in panels A, B, and C. R, right; L, left; A, anterior; P, posterior.

Fig. 4. Correlation relations between quantitative variables. A. Correlation relations that indicate $p$ values $<0.05$ are shown. Positive and negative correlations are indicated as a solid and a broken line. B. Scatter plot between pre-operative CSDH volume and thickness are shown. The regression line was indicated as a red line and $r$ is the correlation coefficient. Red dashed lines correspond to $36.3 \mathrm{~mm}$ and $155 \mathrm{ml}$.

Fig. 5. ROC and Kaplan-Meier curves. In the upper row, ROC curves are indicated. In the lower row, Kaplan-Meier curves are indicated. Quantitative variables include pre-operative CSDH volume (A), CTV (B), post-operative air (C), and age (D). AUC and cut-off values are shown. Kaplan-Meier curves have been plotted using these cut-off values. $P$ values from the log-rank test are indicated. 
medRxiv preprint doi: https://doi.org/10.1101/2022.01.03.22268707; this version posted January 5, 2022. The copyright holder for this preprint (which was not certified by peer review) is the author/funder, who has granted medRxiv a license to display the preprint in perpetuity. It is made available under a CC-BY-NC-ND 4.0 International license.

Table. 1 Descriptive statistics regarding demographic characteristics, quantitative measures using DICOM CT images, and pre- and postoperative clinical information in $304 \mathrm{CSDH}$ cases. Statistically significant $p$ values are flagged with an asterisk.

\begin{tabular}{|c|c|c|c|c|}
\hline Characteristics analyzed & $\begin{array}{c}\text { Patients n } \\
(\%)\end{array}$ & $\begin{array}{c}\text { nRrR } \\
(\%)\end{array}$ & $\begin{array}{l}\text { RrR } \\
(\%)\end{array}$ & $p$-value \\
\hline \multicolumn{5}{|l|}{ Sex } \\
\hline Male & $224(74)$ & $196(88)$ & $28(12)$ & 0.77 \\
\hline Female & $80(26)$ & $71(89)$ & $9(11)$ & \\
\hline \multicolumn{5}{|l|}{ Mean age \pm SD (years) } \\
\hline Male & $\begin{array}{ll}76.3 & \pm \\
10.4 & \end{array}$ & $75.8 \pm 10.5$ & $79.6 \pm 9.4$ & 0.091 (Rank sum) \\
\hline Female & $80.7 \pm 7.8$ & $80.4 \pm 8.1$ & $83.1 \pm 5.2$ & 0.45 (Rank sum) \\
\hline \multicolumn{5}{|l|}{ Age categories (years) } \\
\hline$<=75$ & $95(31)$ & $89(94)$ & $6(6)$ & $* 0.035$ \\
\hline$>75$ & $209(69)$ & $178(85)$ & $31(15)$ & \\
\hline \multicolumn{5}{|l|}{ Laterality } \\
\hline Left & $159(52)$ & $140(88)$ & $19(12)$ & 0.90 \\
\hline Right & $145(48)$ & $127(88)$ & $18(12)$ & \\
\hline \multicolumn{5}{|l|}{ Bilateral CSDH } \\
\hline Yes & $77(25)$ & $65(84)$ & $12(16)$ & 0.29 \\
\hline No & $227(75)$ & $202(89)$ & $25(11)$ & \\
\hline \multicolumn{5}{|l|}{ Midline shift } \\
\hline Yes & $221(72)$ & $195(88)$ & $26(12)$ & 0.72 \\
\hline No & $83(28)$ & $72(87)$ & $11(13)$ & \\
\hline $\begin{array}{l}\text { Pre-operative CSDH volume } \pm \text { SD } \\
\text { (ml) }\end{array}$ & & $116.1 \pm 36.7$ & $136.1 \pm 37.7$ & $\begin{array}{l}* 0.0029 \quad \text { (Rank } \\
\text { sum) }\end{array}$ \\
\hline $\begin{array}{l}\text { Pre-operative CSDH thickness } \pm \text { SD } \\
(\mathrm{mm})\end{array}$ & & $28.0 \pm 5.2$ & $29.0 \pm 6.6$ & 0.44 (Rank sum) \\
\hline Pre-operative CTV \pm SD & & $33.5 \pm 7.3$ & $30.4 \pm 7.6$ & $\begin{array}{l}\begin{array}{l}* 0.0075 \\
\text { sum) }\end{array} \text { (Rank } \\
\end{array}$ \\
\hline Pre-operative SD of CTV \pm SD & & $9.7 \pm 2.6$ & $10.3 \pm 2.6$ & 0.16 (Rank sum) \\
\hline \multicolumn{5}{|l|}{ Subtype } \\
\hline Homogeneous & $125(41)$ & $109(87)$ & $16(13)$ & 0.29 \\
\hline Laminar & $18(6)$ & $15(83)$ & $3(17)$ & \\
\hline Separate & $74(24)$ & $62(84)$ & $12(16)$ & \\
\hline Trabecular & $87(29)$ & $81(93)$ & $6(7)$ & \\
\hline \multicolumn{5}{|l|}{ Subtype CTV \pm SD } \\
\hline Homogeneous & $33.1 \pm 9.5$ & & & $\begin{array}{ll}0.21 & \text { (Kruskal- } \\
\text { Wallis) }\end{array}$ \\
\hline Laminar & $35.4 \pm 5.8$ & & & \\
\hline Separate & $33.5 \pm 5.5$ & & & \\
\hline Trabecular & $32.5 \pm 5.3$ & & & \\
\hline \multicolumn{5}{|l|}{ SD of subtype CTV \pm SD } \\
\hline Homogeneous & $8.4 \pm 1.9$ & & & $\begin{array}{l}4.9 \times 10^{-29} \\
\text { (Kruskal-Wallis) }\end{array}$ \\
\hline Laminar & $9.7 \pm 2.5$ & & & \\
\hline Separate & $12.0 \pm 2.4$ & & & \\
\hline Trabecular & $10.0 \pm 2.2$ & & & \\
\hline
\end{tabular}


medRxiv preprint doi: https://doi.org/10.1101/2022.01.03.22268707; this version posted January 5, 2022. The copyright holder for this preprint (which was not certified by peer review) is the author/funder, who has granted medRxiv a license to display the preprint in perpetuity. It is made available under a CC-BY-NC-ND 4.0 International license .

\begin{tabular}{|c|c|c|c|c|}
\hline $\begin{array}{l}\text { Sub-grading in homogeneous group } \\
* 1\end{array}$ & & & & \\
\hline Hypodensity $(\mathrm{CTV}<30)$ & $40(32)$ & $32(80)$ & $8(20)$ & 0.25 \\
\hline Isodensity $(30 \leqq \mathrm{CTV}<40)$ & $51(41)$ & $46(90)$ & $5(10)$ & \\
\hline Hyperdensity $(\mathrm{CTV} \geqq 40)$ & $34(27)$ & $31(91)$ & $3(9)$ & \\
\hline \multicolumn{5}{|l|}{ MNI coordinates of thickness \pm SD } \\
\hline $\mathrm{X}$ (absolute values) & & $53.3 \pm 9.9$ & $52.5 \pm 11.2$ & 0.77 (Rank sum) \\
\hline $\mathrm{Y}$ & & $2.0 \pm 40.0$ & $11.0 \pm 38.6$ & 0.18 (Rank sum) \\
\hline $\mathrm{Z}$ & & $29.7 \pm 18.3$ & $28.8 \pm 16.2$ & 0.63 (Rank sum) \\
\hline \multicolumn{5}{|l|}{ MNI coordinate of burr holes \pm SD } \\
\hline X (absolute values) & & $56.0 \pm 7.4$ & $58.0 \pm 7.3$ & 0.061 (Rank sum) \\
\hline $\mathrm{Y}$ & & $-6.1 \pm 18.6$ & $-4.5 \pm 21.5$ & 0.86 (Rank sum) \\
\hline Z & & $42.9 \pm 9.3$ & $39.5 \pm 11.0$ & 0.074 (Rank sum) \\
\hline \multicolumn{5}{|l|}{ Differences of MNI coordinates \pm SD } \\
\hline $\begin{array}{l}\mathrm{X} \text { thick (absolute values) }-\mathrm{X} \text { burr hole } \\
\text { (absolute values) }\end{array}$ & & $-2.7 \pm 11.7$ & $-5.5 \pm 12.4$ & 0.34 (Rank sum) \\
\hline $\mathrm{Y}_{\text {thick }}-\mathrm{Y}_{\text {burr hole }}$ & & $8.1 \pm 40.2$ & $15.5 \pm 39.2$ & 0.29 (Rank sum) \\
\hline$Z_{\text {thick }}-Z_{\text {burr hole }}$ & & $-13.2 \pm 19.7$ & $-10.7 \pm 20.2$ & 0.42 (Rank sum) \\
\hline Distance \pm SD & & $42.0 \pm 24.8$ & $41.9 \pm 26.3$ & 0.80 (Rank sum) \\
\hline $\begin{array}{l}\text { Post-operative CSDH volume } \pm \text { SD } \\
(\mathrm{ml})\end{array}$ & & $49.8 \pm 29.8$ & $69.0 \pm 32.6$ & $\begin{array}{l}* 0.00024 \quad \text { (Rank } \\
\text { sum) }\end{array}$ \\
\hline $\begin{array}{l}\text { Drainage volume between pre- and } \\
\text { post-operative } \pm \text { SD }(\mathrm{ml})\end{array}$ & & $66.3 \pm 34.7$ & $67.8 \pm 34.9$ & 0.49 (Rank sum) \\
\hline $\begin{array}{l}\text { Drainage ratio between pre- and } \\
\text { post-operative } \pm \text { SD }\end{array}$ & & $0.57 \pm 0.22$ & $0.49 \pm 0.22$ & 0.073 (Rank sum) \\
\hline Post-operative air \pm SD (ml) & & $11.7 \pm 17.7$ & $12.3 \pm 11.9$ & 0.13 (Rank sum) \\
\hline Career of surgeons (years) & & $9.6 \pm 4.5$ & $9.6 \pm 4.8$ & 0.91 (Rank sum) \\
\hline $\begin{array}{l}\text { Few months later CSDH volume } \pm \\
\text { SD }(\mathrm{ml}) * 2\end{array}$ & & $25.6 \pm 30.9$ & $89.8 \pm 40.9$ & $\begin{array}{l}* 1.0 \times 10^{-12}(\text { Rank } \\
\text { sum) }\end{array}$ \\
\hline \multicolumn{5}{|l|}{ Drainage tube direction $* 3$} \\
\hline Anterior & $140(46)$ & $121(86)$ & $19(14)$ & 0.52 \\
\hline Posterior & $162(54)$ & $144(89)$ & $18(11)$ & \\
\hline \multicolumn{5}{|l|}{$\begin{array}{l}\text { Air volume related to } \\
\text { drainage tube direction } * 3\end{array}$} \\
\hline Anterior & $\begin{array}{ll}10.3 \quad \pm \\
12.1 & \end{array}$ & $10.4 \pm 12.6$ & $9.8 \pm 8.1$ & 0.59 (Rank sum) \\
\hline Posterior & $\begin{array}{l}13.0 \quad \pm \\
20.5\end{array}$ & $12.8 \pm 21.1$ & $14.9 \pm 14.7$ & 0.13 (Rank sum) \\
\hline \multicolumn{5}{|l|}{ Irrigation *4 } \\
\hline Do & $96(37)$ & $85(89)$ & $11(11)$ & 0.33 \\
\hline Undo & $164(63)$ & $138(84)$ & $26(16)$ & \\
\hline \multicolumn{5}{|l|}{$\begin{array}{l}\text { Clinical information before } \\
\text { operation } * 5\end{array}$} \\
\hline \multicolumn{5}{|l|}{ Headache } \\
\hline Yes & 49 (19) & $40(82)$ & $9(18)$ & 0.35 \\
\hline No & $212(81)$ & $184(87)$ & $28(13)$ & \\
\hline \multicolumn{5}{|l|}{ Dementia } \\
\hline Yes & $65(25)$ & $52(80)$ & $13(20)$ & 0.12 \\
\hline
\end{tabular}


medRxiv preprint doi: https://doi.org/10.1101/2022.01.03.22268707; this version posted January 5, 2022. The copyright holder for this preprint (which was not certified by peer review) is the author/funder, who has granted medRxiv a license to display the preprint in perpetuity. It is made available under a CC-BY-NC-ND 4.0 International license .

\begin{tabular}{|c|c|c|c|c|}
\hline No & $196(75)$ & $172(88)$ & $24(12)$ & \\
\hline \multicolumn{5}{|c|}{ Aphasia } \\
\hline Yes & $13(5)$ & $11(85)$ & $2(15)$ & 0.90 \\
\hline No & $248(95)$ & $213(86)$ & $35(14)$ & \\
\hline \multicolumn{5}{|c|}{ Hemiplegia } \\
\hline Yes & $166(64)$ & $142(86)$ & $24(14)$ & 0.86 \\
\hline No & $95(36)$ & $82(86)$ & $13(14)$ & \\
\hline \multicolumn{5}{|c|}{ Gait disturbance } \\
\hline Yes & \begin{tabular}{|l|}
$223(85)$ \\
\end{tabular} & $190(85)$ & $33(15)$ & 0.49 \\
\hline No & $38(15)$ & $34(89)$ & $4(11)$ & \\
\hline \multicolumn{5}{|l|}{ GCS } \\
\hline 15 & $145(56)$ & $130(90)$ & $15(10)$ & $* 0.047$ \\
\hline $3-14$ & $116(44)$ & $94(81)$ & $22(19)$ & \\
\hline \multicolumn{5}{|c|}{ Anticoagulant } \\
\hline Yes & $31(12)$ & $29(94)$ & $2(6)$ & 0.19 \\
\hline No & $230(88)$ & $195(85)$ & $35(15)$ & \\
\hline \multicolumn{5}{|c|}{ Antiplatelet } \\
\hline Yes & $49(19)$ & $44(90)$ & $5(10)$ & 0.38 \\
\hline No & $212(81)$ & $180(85)$ & $32(15)$ & \\
\hline \multicolumn{5}{|c|}{$\begin{array}{lll}\text { Both of } & \text { anticoagulant } & \text { and } \\
\text { antiplatelet }\end{array}$} \\
\hline Yes & $8(3)$ & $8(100)$ & $0(0)$ & 0.24 \\
\hline No & $253(97)$ & $216(85)$ & $37(15)$ & \\
\hline \multicolumn{5}{|c|}{ Either anticoagulant or antiplatelet } \\
\hline Yes & $72(28)$ & $65(90)$ & $7(10)$ & 0.20 \\
\hline No & $189(72)$ & $159(84)$ & $30(16)$ & \\
\hline \multicolumn{5}{|c|}{$\begin{array}{l}\text { Clinical information after operation } \\
* 6\end{array}$} \\
\hline \multicolumn{5}{|c|}{ Complication } \\
\hline Yes & $17(6)$ & $12(71)$ & $5(29)$ & 0.061 \\
\hline No & $245(94)$ & $213(87)$ & $32(13)$ & \\
\hline \multicolumn{5}{|c|}{ Dementia } \\
\hline Yes & $48(18)$ & $38(79)$ & $10(21)$ & 0.14 \\
\hline No & $214(82)$ & $187(87)$ & $27(13)$ & \\
\hline \multicolumn{5}{|c|}{ Hemiplegia } \\
\hline Yes & $9(3)$ & $4(44)$ & $5(56)$ & $* \mathbf{0 . 0 0 0 2 8}$ \\
\hline No & $253(97)$ & $221(87)$ & $32(13)$ & \\
\hline \multicolumn{5}{|c|}{ Gait disturbance } \\
\hline Yes & $36(13)$ & $25(69)$ & $11(31)$ & \begin{tabular}{|l|}
$* 0.0023$ \\
\end{tabular} \\
\hline No & $226(87)$ & $200(88)$ & $26(12)$ & \\
\hline \multicolumn{5}{|c|}{ GCS score } \\
\hline 15 & $203(77)$ & $178(88)$ & $25(12)$ & 0.12 \\
\hline $3-14$ & $59(23)$ & $47(80)$ & $12(20)$ & \\
\hline
\end{tabular}

Abbreviations: CSDH, chronic subdural hematoma; CTV, computed tomography values; GCS, Glasgow Coma Scale; MNI, Montreal Neurological Institute; nRrR, non-recurrence requiring reoperation; RrR, recurrence requiring reoperation; $\mathrm{SD}$, standard deviation

*1: 125 cases classified into the homogenous subtype were analyzed

*2: 288 cases were analyzed 
medRxiv preprint doi: https://doi.org/10.1101/2022.01.03.22268707; this version posted January 5, 2022. The copyright holder for this preprint (which was not certified by peer review) is the author/funder, who has granted medRxiv a license to display the preprint in perpetuity.

It is made available under a CC-BY-NC-ND 4.0 International license.

*3: Two cases were not inserted by a drainage tube; therefore, a total of 302 cases were analyzed.

* 4: 260 cases were analyzed

*5: 261 cases were analyzed

*6: 262 cases were analyzed 
medRxiv preprint doi: https://doi.org/10.1101/2022.01.03.22268707; this version posted January 5, 2022. The copyright holder for this preprint (which was not certified by peer review) is the author/funder, who has granted medRxiv a license to display the preprint in perpetuity. It is made available under a CC-BY-NC-ND 4.0 International license .

Table. 2 Univariate and multivariate Cox proportional hazards regression analyses and logistic regression analyses of characteristics related to postoperative recurrence requiring reoperation for CSDH. 261 cases indicated in Fig. 1 were used. Statistically significant $p$ values are flagged with an asterisk.

\begin{tabular}{|c|c|c|c|c|c|c|c|c|}
\hline \multirow{3}{*}{$\begin{array}{l}\text { Characterist } \\
\text { ics analyzed }\end{array}$} & \multicolumn{4}{|c|}{$\begin{array}{c}\text { Cox proportional hazards regression } \\
\text { analyses }\end{array}$} & \multicolumn{4}{|c|}{ Logistic regression analyses } \\
\hline & \multicolumn{2}{|c|}{ Univariate analysis } & \multicolumn{2}{|c|}{$\begin{array}{c}\text { Multivariate } \\
\text { analysis }\end{array}$} & \multicolumn{2}{|c|}{$\begin{array}{c}\text { Univariate } \\
\text { analysis }\end{array}$} & \multicolumn{2}{|c|}{$\begin{array}{l}\text { Multivariate } \\
\text { analysis }\end{array}$} \\
\hline & $\begin{array}{l}\text { HR }(95 \% \\
\text { CI })\end{array}$ & $p$-value & $\begin{array}{c}\text { HR } \\
(95 \% \\
\text { CI })\end{array}$ & $p$-value & $\begin{array}{c}\text { OR } \\
(95 \% \\
\text { CI) }\end{array}$ & $p$-value & $\begin{array}{c}\text { OR } \\
(95 \% \\
\text { CI })\end{array}$ & $p$-value \\
\hline $\begin{array}{l}\text { Pre-operative } \\
\text { CSDH } \\
\text { volume }(\mathrm{ml}) \\
\end{array}$ & $\begin{array}{l}1.01(1.00 \\
-1.02)\end{array}$ & $\begin{array}{c}* 0.003 \\
0\end{array}$ & $\begin{array}{c}1.01 \\
(1.00- \\
1.02)\end{array}$ & $* 0.024$ & $\begin{array}{c}1.01 \\
(1.00- \\
1.02)\end{array}$ & $\begin{array}{c}* 0.003 \\
2\end{array}$ & $\begin{array}{c}1.01 \\
(1.00- \\
1.02)\end{array}$ & $* 0.010$ \\
\hline $\begin{array}{l}\text { Pre-operative } \\
\text { CT values }\end{array}$ & $\begin{array}{l}0.95(0.91 \\
-0.99)\end{array}$ & $* 0.013$ & $\begin{array}{c}0.98 \\
(0.93- \\
1.03) \\
\end{array}$ & 0.38 & $\begin{array}{c}0.96 \\
(0.91- \\
1.00) \\
\end{array}$ & 0.058 & $\begin{array}{c}0.97 \\
(0.92- \\
1.02)\end{array}$ & 0.28 \\
\hline $\begin{array}{l}\text { Post- } \\
\text { operative air } \\
(\mathrm{ml})\end{array}$ & $\begin{array}{l}1.00(0.98 \\
-1.02)\end{array}$ & 0.78 & $\begin{array}{c}0.99 \\
(0.97- \\
1.01) \\
\end{array}$ & 0.32 & $\begin{array}{c}1.00 \\
(0.98- \\
1.02) \\
\end{array}$ & 0.72 & $\begin{array}{c}0.99 \\
(0.97- \\
1.01) \\
\end{array}$ & 0.36 \\
\hline Age (years) & $\begin{array}{c}1.04(1.01 \\
-1.09)\end{array}$ & $* 0.025$ & $\begin{array}{c}1.03 \\
(0.98- \\
1.07) \\
\end{array}$ & 0.21 & $\begin{array}{c}1.04 \\
(1.00- \\
1.08)\end{array}$ & $* 0.049$ & $\begin{array}{c}1.02 \\
(0.97- \\
1.06) \\
\end{array}$ & 0.43 \\
\hline $\begin{array}{l}\text { Pre-operative } \\
\text { GCS score } \\
(3-14) \\
\end{array}$ & $\begin{array}{l}2.36(1.22 \\
-4.56)\end{array}$ & $* 0.011$ & $\begin{array}{c}1.30 \\
(0.62- \\
2.75) \\
\end{array}$ & 0.49 & $\begin{array}{c}2.03 \\
(1.00- \\
4.13)\end{array}$ & 0.050 & $\begin{array}{l}1.27 \\
(0.56- \\
2.90) \\
\end{array}$ & 0.56 \\
\hline $\begin{array}{l}\text { Postoperative } \\
\text { hemiplegia }\end{array}$ & $\begin{array}{l}6.23(2.41 \\
-16.09)\end{array}$ & $\begin{array}{c}* 0.000 \\
16\end{array}$ & $\begin{array}{c}1.70 \\
(0.56- \\
5.17) \\
\end{array}$ & 0.35 & $\begin{array}{c}8.59 \\
(2.18- \\
33.90)\end{array}$ & $\begin{array}{c}* 0.002 \\
0\end{array}$ & $\begin{array}{c}4.63 \\
(0.97- \\
22.16) \\
\end{array}$ & 0.054 \\
\hline $\begin{array}{l}\text { Postoperative } \\
\text { gait } \\
\text { disturbance }\end{array}$ & $\begin{array}{l}6.49(3.14 \\
-13.42)\end{array}$ & $\begin{array}{c}* 0.000 \\
00044\end{array}$ & $\begin{array}{c}3.90 \\
(1.62- \\
9.38)\end{array}$ & $\begin{array}{c}* 0.002 \\
4\end{array}$ & $\begin{array}{c}3.37 \\
(1.48- \\
7.66)\end{array}$ & $\begin{array}{c}* 0.003 \\
6\end{array}$ & $\begin{array}{c}1.83 \\
(0.67- \\
4.97)\end{array}$ & 0.23 \\
\hline
\end{tabular}

Abbreviations: CSDH, chronic subdural hematoma; CT, computed tomography; GCS, Glasgow Coma Scale; HR, hazard ratio; OR, odds ratio 
Pre-operative and post-operative DICOM available

$$
(n=304)
$$

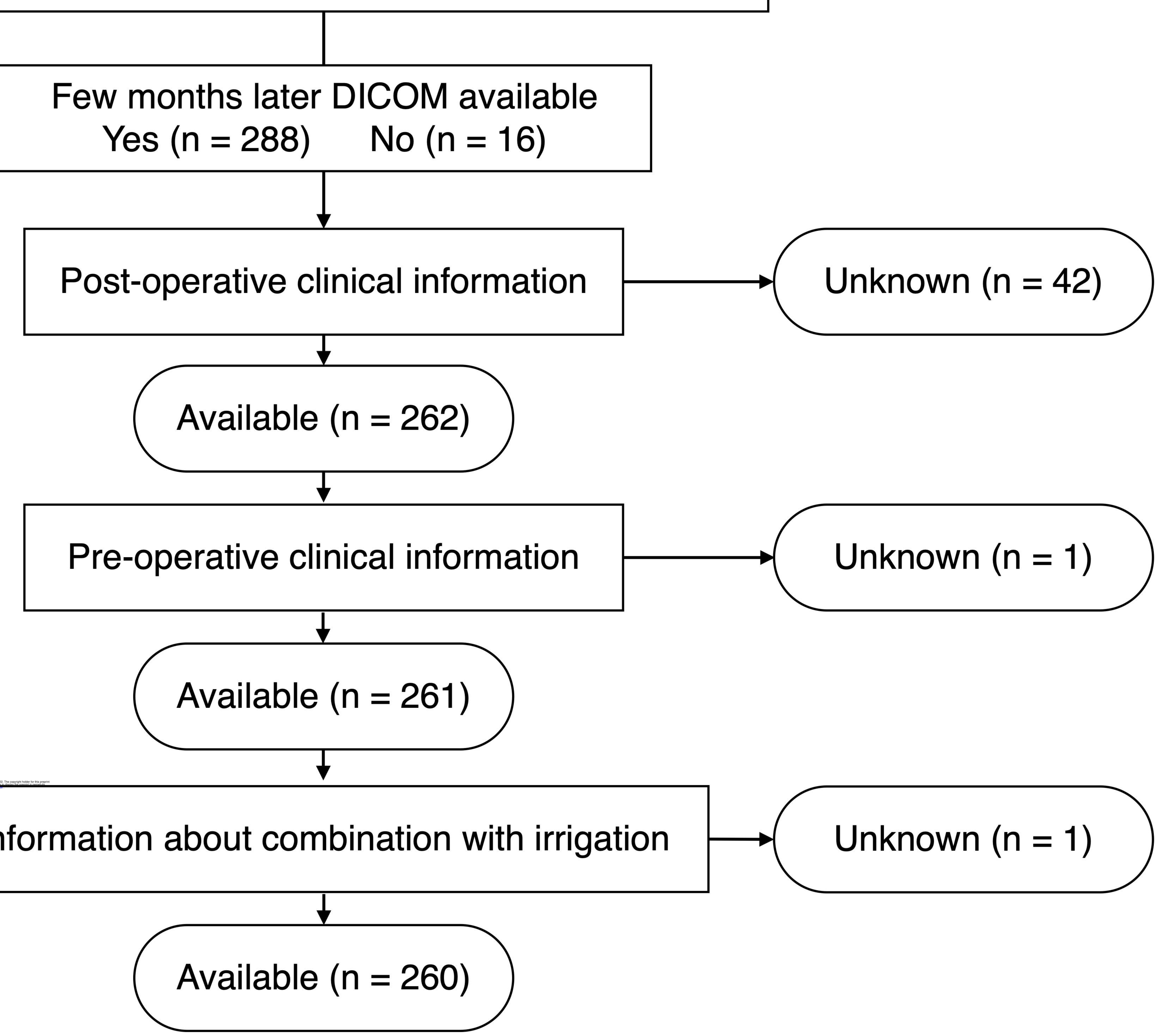


A

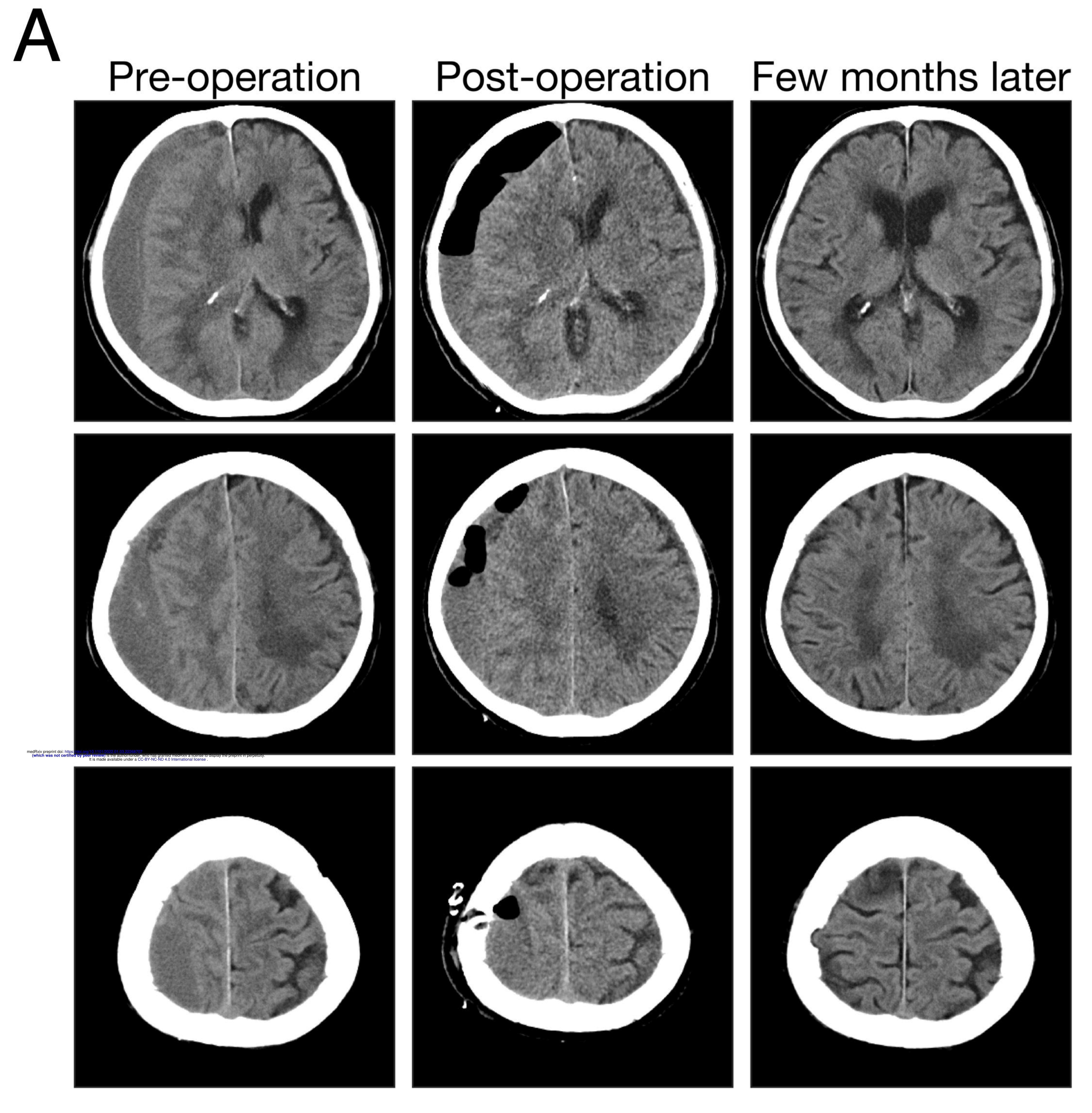

B

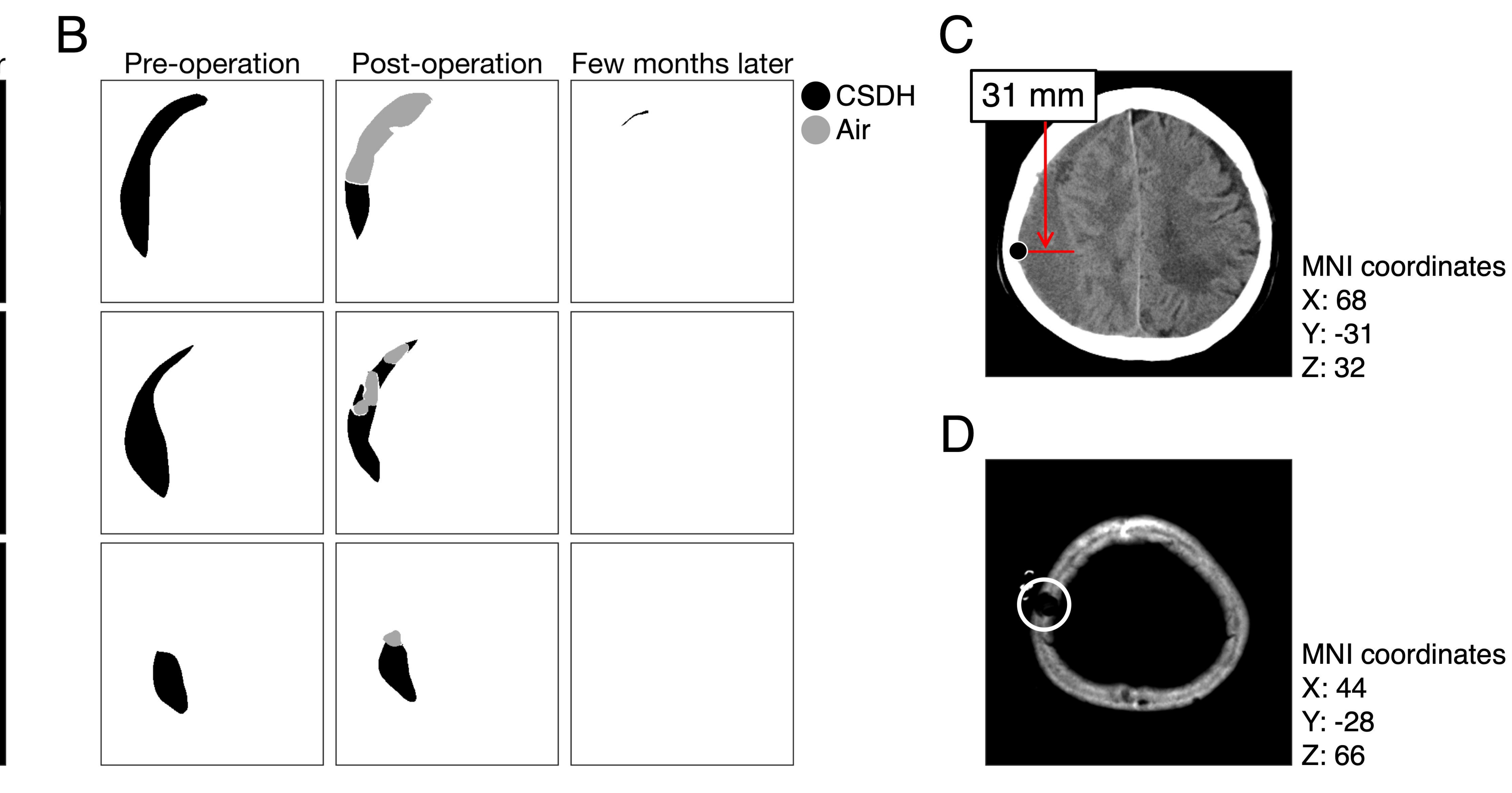
$X: 68$

$Y:-31$

Z: 32

D
MNI coordinates $X: 44$

$Y:-28$
MNI coordinates
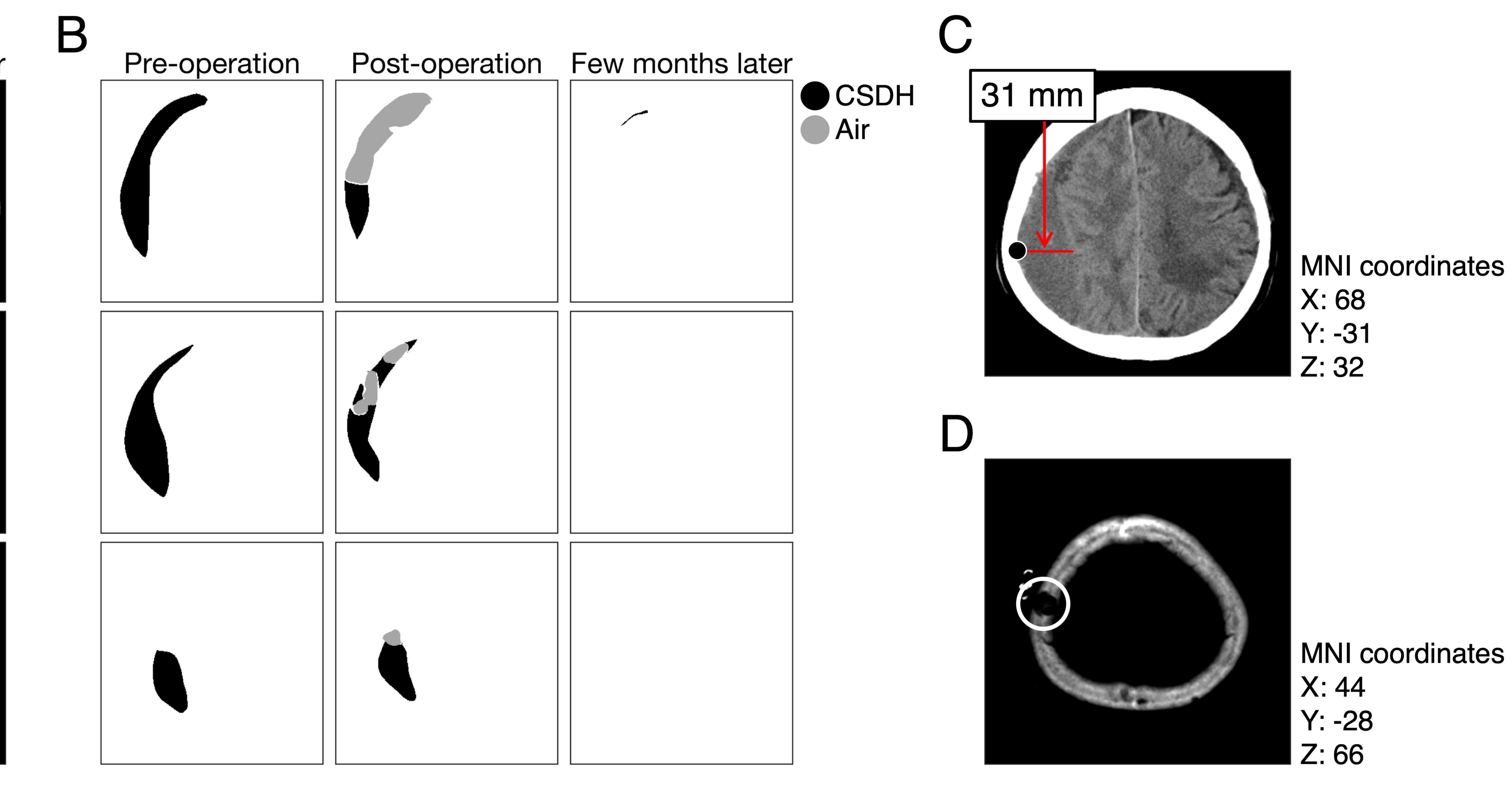

C

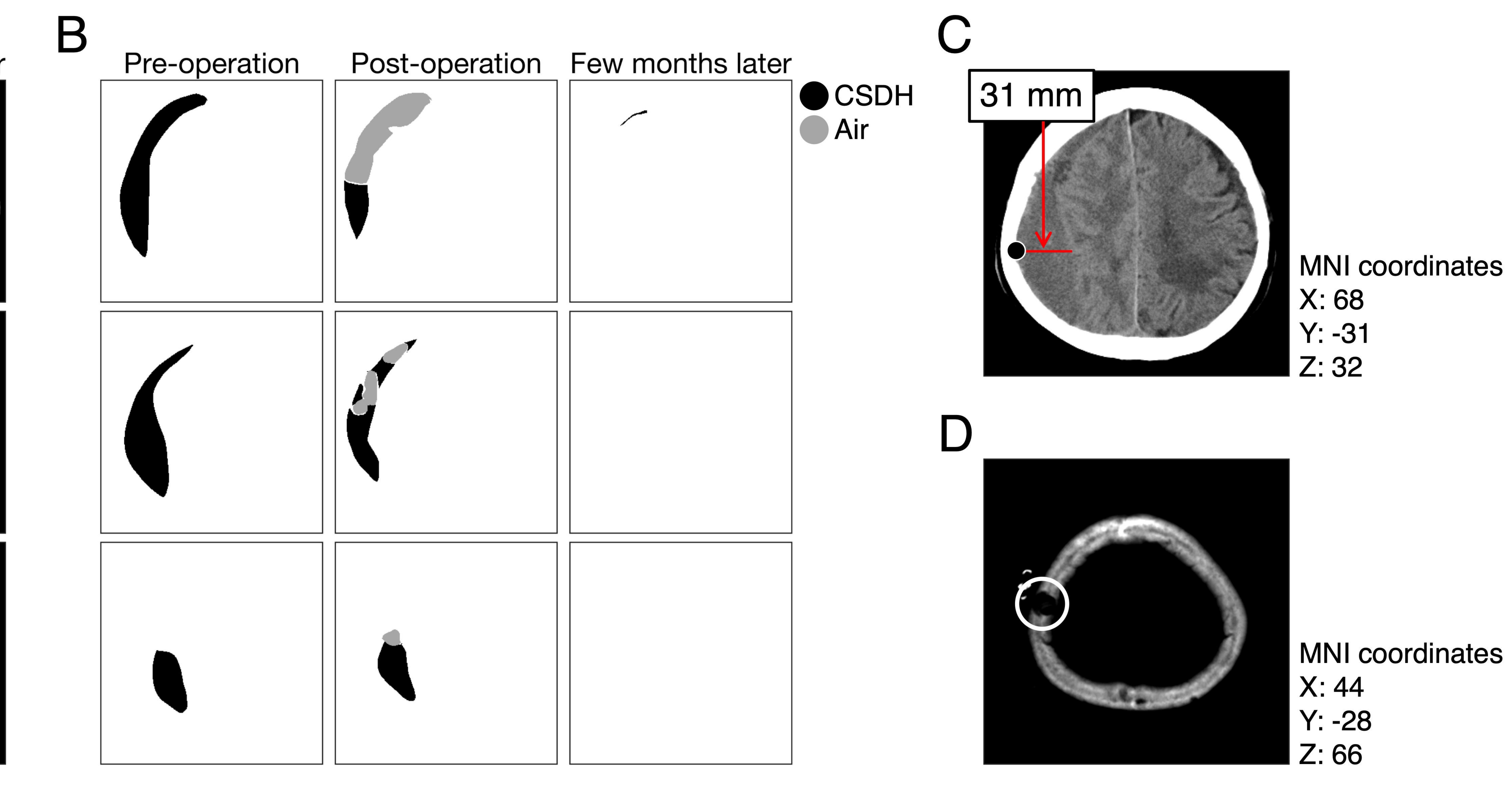



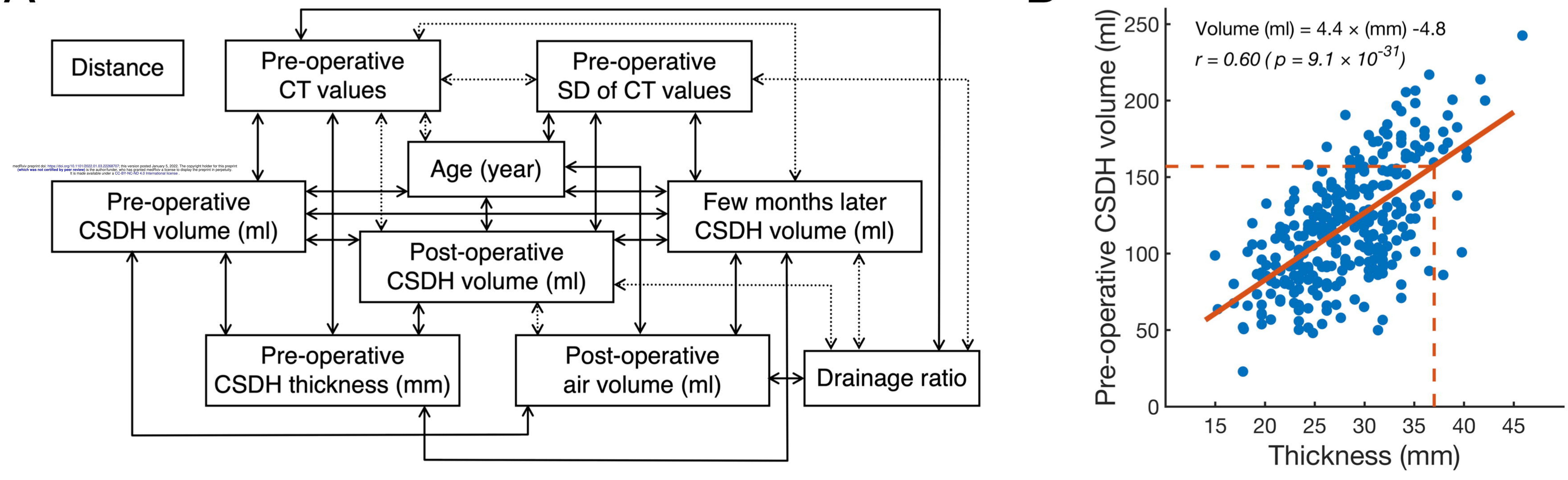
Pre-operative
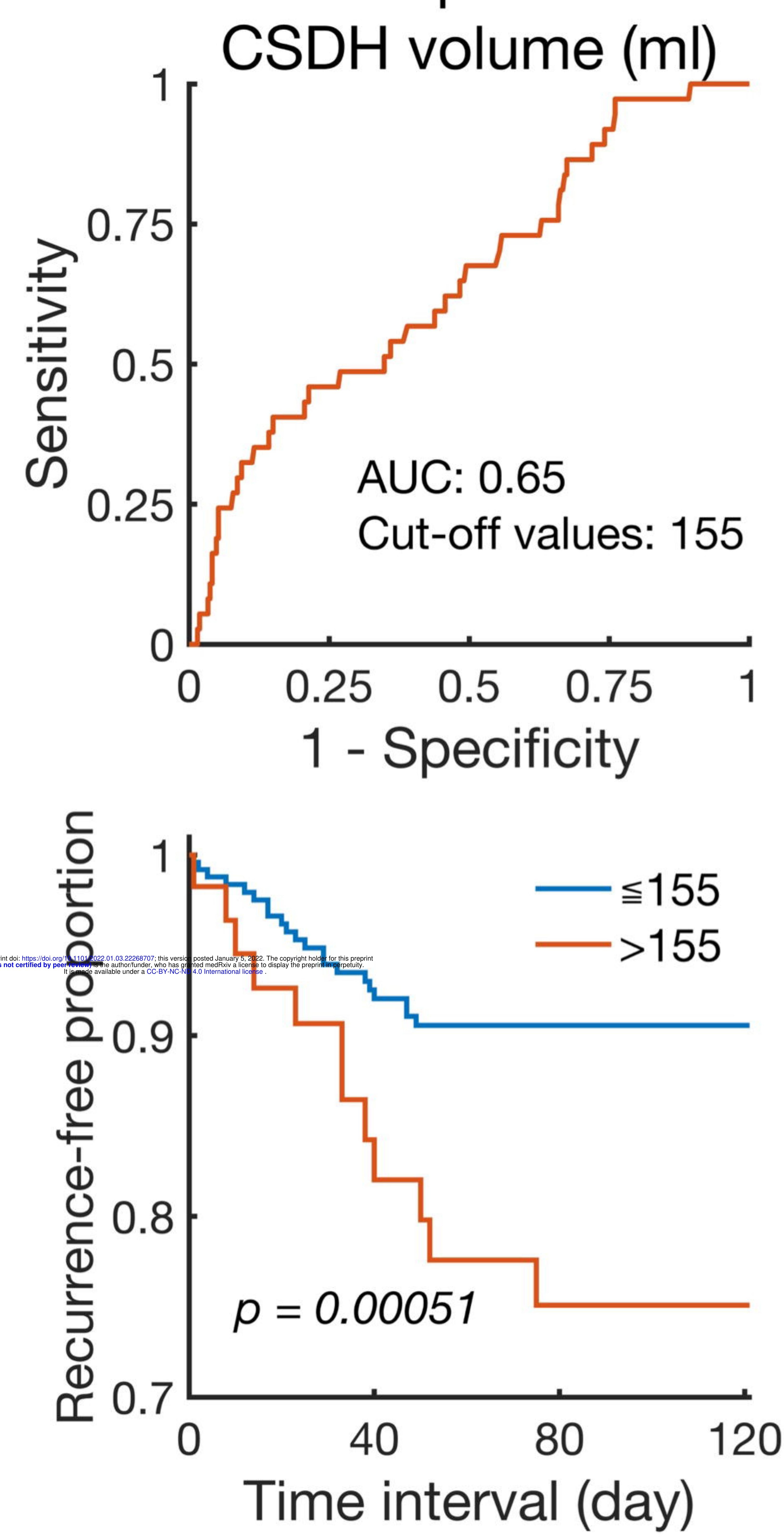

Pre-operative

CT values
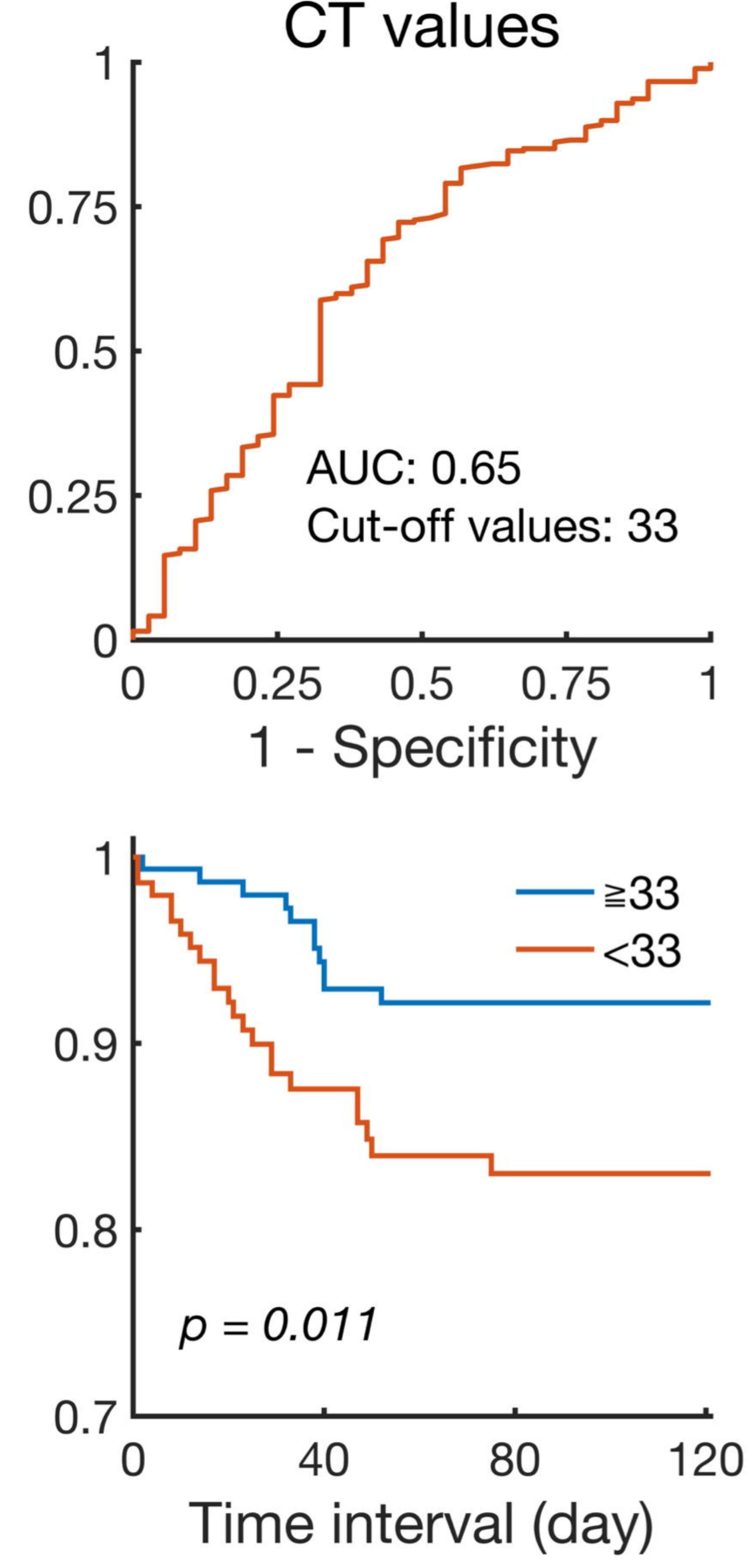

C
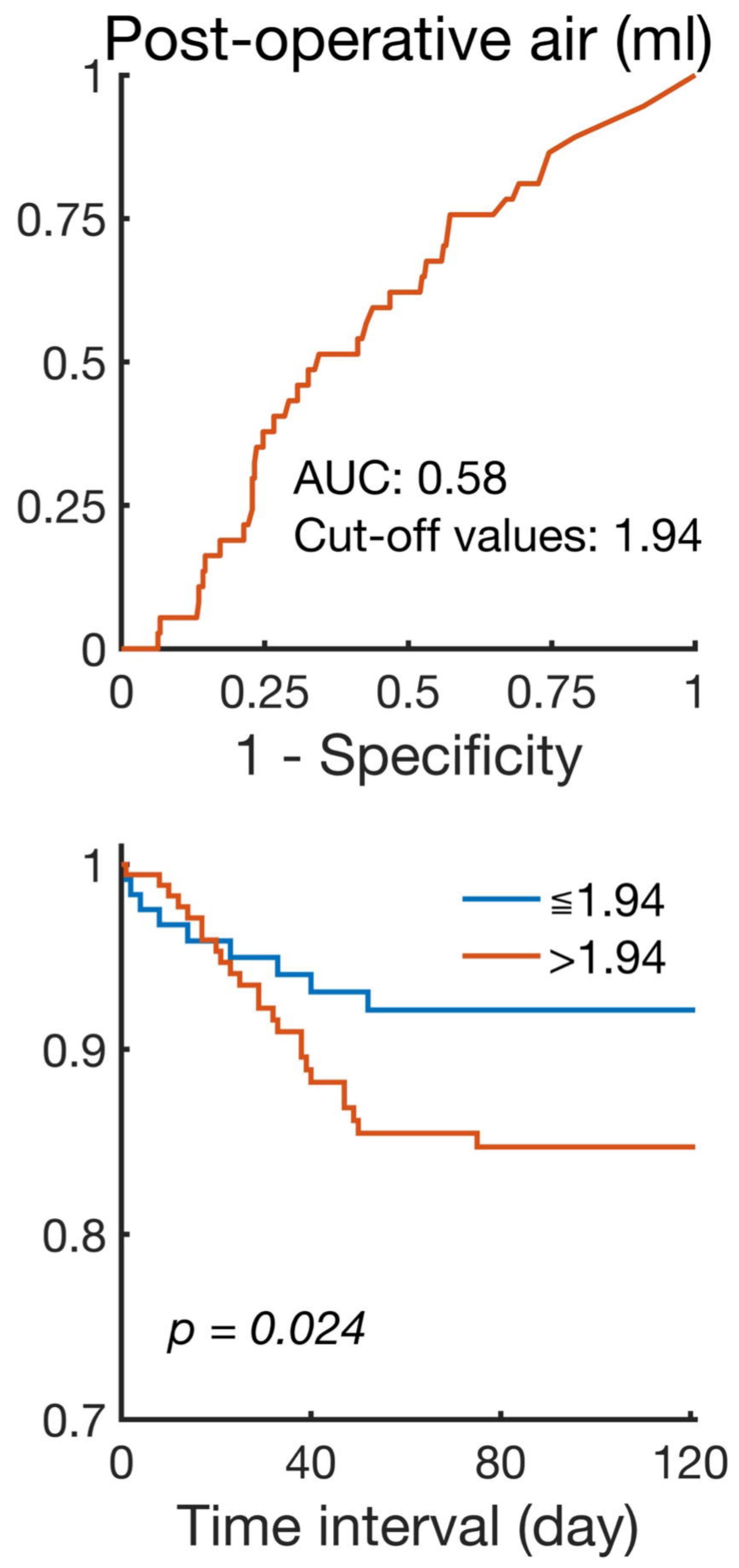

D
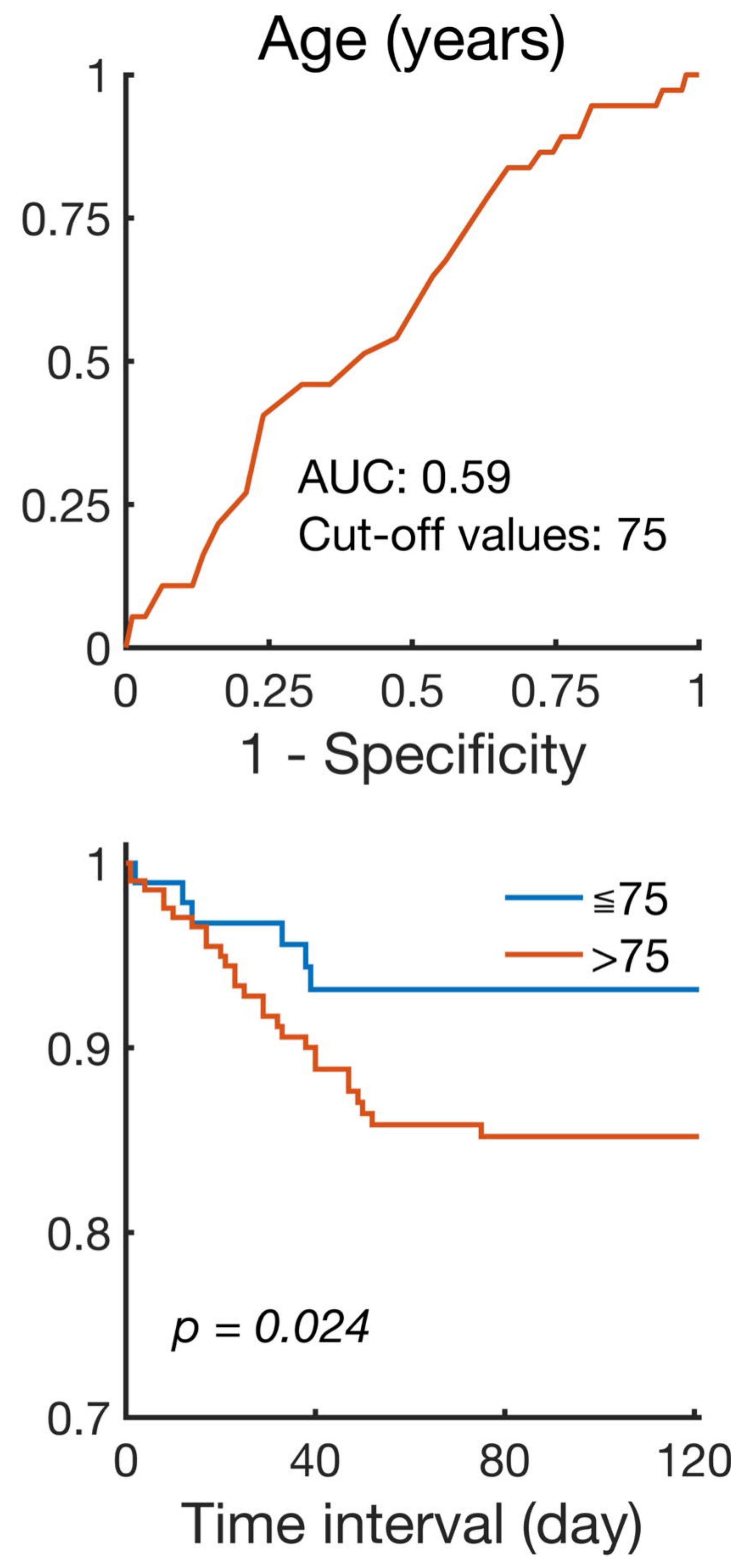